\title{
THE FIRST TYPOGRAPHER IVAN FYODOROV WHO WORKED IN THE RUSSIAN, BELARUSIAN AND UKRAINIAN LANDS ${ }^{1}$
}

\section{Abstract:}

The article discusses the activities of the famous first typographer of Russia, Belarus' and Ukraine: Ivan Fyodorov (c. 1520 - 5th December 1583). The first precisely dated Russian book The Apostle, as well as a few others, were published by him in Moscow in 1564. At the end of the 1560s Ivan Fyodorov published a number of books at the Zabludov manor of the Belarusian Orthodox magnates Khotkeviches including The Didactic Gospel in 1569 . From the 1570 s to the early 1580 s he went on to publish a number of other books in Lvov and Ostrog. Among these publications was the first printed Bible in Church Slavonic: the Ostrog Bible.

\section{Keywords:}

Ivan Fyodorov, Cyril and Methodius heritage, East Slavic early printed book culture, Ostrog Bible.

АННОтация: Ю.А. ЛАБЫНЦЕВ. «ПЕРВОПЕЧАТНИК ИВАН ФЕДОРОВ, РАБОТАВШИЙ В РУССКИХ, БЕЛОРУССКИХ И УКРАИНСКИХ ЗЕМЛЯХ».

В статье рассматривается деятельность знаменитого русского, белорусского и украинского первопечатника Ивана Федорова (ок. 1520 - 5 декабря 1583 г.). В 1564 г. он выпустил в Москве первую точно датированную русскую книгу «Апостол», а затем несколько других книг. В конце 1560-х годов в Заблудове - имении белорусских православных магнатов Ходкевичей. Иван Федоров напечатал еще ряд изданий, в их числе «Евангелие учительное» 1569 г. А в 1570-х - начале 1580-х годов во Львове и Остроге он издал ряд других книг. Среди них была и первая печатная Библия на церковнославянском языке - Острожская библия.

\section{Ключевые слова:}

Иван Федоров, кирилло-мефодиевское наследие, восточнославянская старопечатная книжность.

Tan Fyodorov was a Russian, Belarusian and Ukrainian printing pioneer, publisher of the first dated book printed in Russian. The exact time and place of Ivan Fyodorov's birth is not known, but in his publications he constantly emphasized his Moscow origins: "Ivan Fyodorovich, Muscovite Typographer," "Ivan Fyodorovich, typographer from Moscow."

Typography appeared in Moscow in the middle of the 16th century, when, at the behest of Tsar Ivan the Terrible and with the blessing of Metropolitan Macarius, a printing house was founded in 1563. Its beginning and successful

\footnotetext{
1 The work was carried out with the financial support of the RFBR (grant № 18-512-76004).
} 
development were associated with the activities of Ivan Fyodorov and Pyotr Timofeev Mstislavets. It should be noted that by that time several anonymous books had already been published in Moscow without any indication of the place and date of the publication. Finally, on 1st March1564, was published The Apostle, the first dated book printed in Russian. The afterword, most likely composed by Ivan Fyodorov himself, sets out the background of the founding of the printing house. It is reported that, by decision of Tsar Ivan the Terrible, people began to buy manuscript books in the marketplace, but they were full of the mistakes of ignorant copyists. Therefore, as the epilogue says, it was ordered that the royal treasury set up a printing house and begin a printing business. The deacon of the Church of St Nicholas Gostunsky in the Kremlin, Ivan Fyodorov, and Pyotr Timofeev Mstislavets were appointed as the "producers" of this publishing undertaking.

After the publication in Moscow of The Apostle in 1564, the first typographers published two editions of The Chapel, which was used in Russia for teaching reading and writing, but they soon left Moscow, taking with them some of the printing materials. Ivan Fyodorov himself explained the reasons for his departure as troubles due to the bitterness of ignorant people: "not from the tsar himself, but from the many civic and spiritual leaders and teachers "who, out of envy, accused the typographers "of various heresies, wishing to turn good into evil." They were therefore forced to leave their homeland and move to other "unknown countries," which were the lands of the Grand Duchy of Lithuania and Poland. Here the first typographers found refuge on the estate of the magnate Gregory Khodkevich of Zabludov and soon began to create an Orthodox printing house. On 8th July1568, in Zabludov they started to print their first book, The Didactical Gospel. The set was printed using fonts that they had brought from Moscow; the headpieces, endings and initial letters of the publication

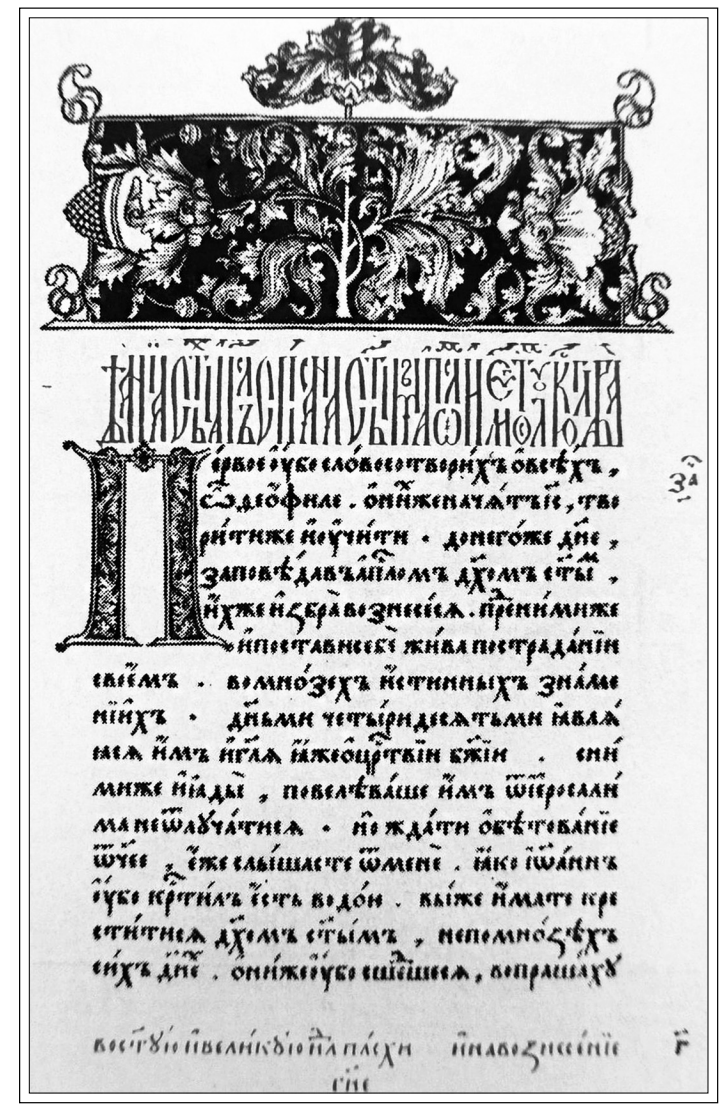

The title page of The Apostle. Moscow, 1564 
were also of Moscow origin: Ivan Fyodorov and Pyotr Timofeev Mstislavets used them with the imprint of the The Apostle in 1564. The Didactic Gospel was published on 17th March 1569. This book also included one of the writings of the famous Old Russian preacher of the 12th century, Cyril of Turov. The following year in Zabudov, Ivan Fzodorov, without Pyotr Timofeev Mstislavets (who later began to print books in Vilna), released The Psalter with the The Epistle, which was widely used for literacy purposes.

In 1572, after Khodkevich's decision to close the Zabludov printing house, Ivan Fyodorov moved to Lvov, where two years later he published the famous The Apostle and The Primer. These two books laid the foundation for book printing in the Ukrainian lands, and Ivan Fyodorov is rightfully considered the founder of Ukrainian book printing. The main text of the first copy of The Apostle printed in Ukraine was completely repeated by the copy of The Apostle printed in Moscow in 1564, but three small initial articles and an extensive afterword by Ivan Fyodorov about the beginning of printing were added to it. Unlike Moscow and Zabludov, where the first typographer received great moral and material support from the powerful, in Lvov he was not given that. Here he saw a blatant indifference to the craft of printing, and only a few "low-ranking" Orthodox clergy and Lvov laypeople not belonging to the nobility were ready to help.

In 1579 Ivan Fyodorov, at the invitation of Prince Constantine of Ostrog, arrived in Ostrog, where the prince gathered prominent scholars of that time to prepare and publish the first full printed Bible in Church Slavonic. Before that goal was reached Ivan Fyodorov printed in Ostrog The Alphabet Book (1578), The Primer (c. 1580), A book of the things most needed in short order for the sake of finding The New Testament in the book (1580), The Chronology by Andrey Rymsha (1581). In preparation for the publication of The Bible, the pioneering typographer significantly expanded and staffed the Ostrog printing house: he prepared a large number of necessary printing tools and accumulated a huge stock of paper for printing such a voluminous publication. In 1581 the Bible was published in Ostrog: a remarkable monument of world typographic art, the first full Bible in the Church Slavonic language. Ivan Fyodorov himself, who was an excellent textual critic and an expert in the Church Slavonic language, was directly involved in preparing the manuscript. At the beginning of 1583 , he returned to Lvov, where he died in December 1583 and was buried at the Monastery of St Onuphrios.

The name of Ivan Fyodorov is widely known in many countries worldwide. It is especially precious to the people of Russia, Belarus' and Ukraine, where his activities left their deepest mark. He was an outstanding individual: a member of the clergy, a printing pioneer, an inventor, a writer. As a writer, Ivan Fyodorov left us several of his works in the afterwords to the editions he published. A special place among them belongs to the afterword to the Lvov Apostle of 1574, which he called The Tale. It became the first ever printed story by a Russian author. However, Ivan Fyodorov's main exploit was his activity as a typographer 
and publisher. This was well understood by his contemporaries, who engraved on his tombstone in Lvov: "Ivan Fyodorovich, Drukar Moskvitin (Typographer from Moscow), ... Drukar (Typographer) of books never before seen."

Ivan Fyodorov's books are widely distributed around the world, and most of them are, of course, in Russia and Ukraine, followed by Serbia, Poland, Great Britain, Bulgaria and other countries. About 70 copies of the Moscow Apostle of 1564 have survived to the present day, most of which are located in different Russian cities, with the majority being in Moscow: one third of those currently known. Copies of this book are also to be found in a number of other countries: Great Britain, the USA, Kyrgyzstan, the Czech Republic, Latvia, and, of course, in Ukraine, where a tenth of them are preserved. About 130 copies of the Lvov Apostle of 1574 have survived, more than half of which are in Russia, including a quarter in Moscow.

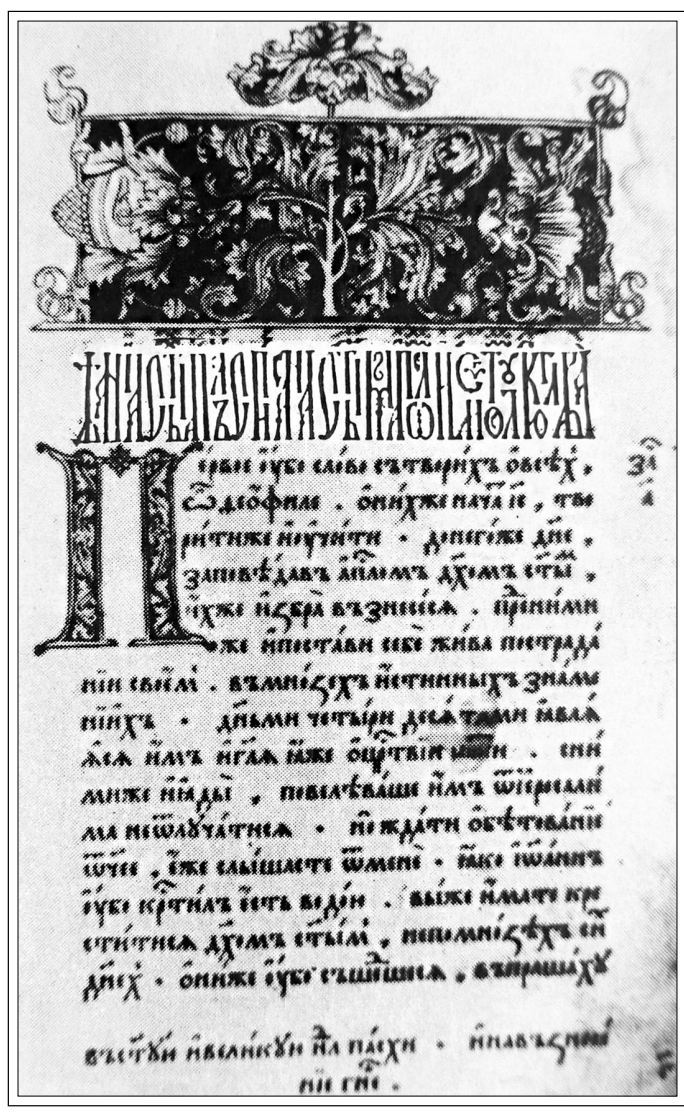

The title page of The Apostle. Lvov, 1574 Copies of this book are also to be found in Poland, Lithuania, Greece, Great Britain, Austria, Hungary, Canada, Belarus', Bulgaria, Serbia, Italy, the Czech Republic and Sweden. A quarter of all copies of the Lvov Apostle of 1574 are to be found in Ukraine, 14 of them in Lvov. A special fate awaited The Didactical Gospel of Zabludov (1569), which had a significant impact on the Orthodox, both within the Grand Duchy of Lithuania and far beyond, as far as Moscovy and the Balkans. This book was repeatedly reprinted, used for work on other publications, copied in different countries, translated into other languages. About fifty copies of The Teaching Gospel of Ostrog (1569) have survived to the present day and are now preserved in many countries on different continents: in Poland, the USA, Serbia, Lithuania, Ukraine, Belarus, etc. Most of the copies are in Russia: in Vladimir, Nizhny Novgorod, St. Petersburg, Novosibirsk, Petrozavodsk, Yekaterinburg and especially in Moscow, where a total of about 20 copies of this edition are stored. Numerous records of the surviving copies attest to the unusually wide distribution of the book throughout the Orthodox world. Very soon after its publication 
The Teaching Gospel of Ostrog found its way to the Bulgarians, Russians, Serbs and other Orthodox peoples, spread to the lands of the Grand Duchy of Lithuania and the Kingdom of Poland. About 400 copies of The Bible of Ostrog have survived to this day, and every year more and more copies are discovered. It is not an exaggeration to say that they are distributed throughout the world. The issue of the circulation of the Ostrog Bible has not yet been resolved, but it was undoubtedly very large at that time. However, the huge number of surviving copies of this book is also explained by the very careful attitude to this outstanding document of Slavic booklore. The publication of the first Bible printed in Church Slavonic in Ostrog in 1581 not only completed the centuries-old history of the creation of a complete "Slavonic" biblical code, but also laid a new, solid foundation for the reception of the text of the Holy Scripture by many peoples, this thousand-year-old core of the entire European cultural tradition.

The Deacon of the Kremlin Church of St Nicholas Gostunsky, "Ivan Fyodorov, a Muscovite son," is one of those historical figures who happened to become one of the main conduits of the broadest and largest communication of the ancient printed Church Slavonic tradition. Ivan Fyodorov's multifaceted creative activity in Moscow, Belarus' and Ukraine is one of the brightest pages in the history of these countries. In the history of East Slavic cultural relations, including Russian-Ukrainian, it is difficult to find an example that so vividly demonstrates the centuries-old spiritual kinship of these two peoples. During his difficult wandering life, which ended in Lvov in December 1583, he printed a number of publications that have become classics and exemplary not only as objects of the world's typographic art, but also as monuments to the thousand-year-old Church Slavonic book tradition, which still protects and attests to the spiritual and cultural unity of the eastern and southern Slavs.

Streets in a number of cities have been named after Ivan Fyodorov, statues in Moscow and Lvov have been erected to him, and writers dedicate works of art to him. On 23 July 2010 the Moscow State University of Publishing was named after Ivan Fyodorov in connection with the 80th anniversary of the founding of the university.

Translated by Igor Kaliganov

\section{BIBLIOGRAPHY}

Labyntsev Iu., Shchavinskaia L. "Napechatana... Ivanom Fedorovym... Moskvitinom". Moscow, 2007.

Nemirovskii EL. Ivan Fedorov i ego epokha: Entsiklopediia. Moscow, 2007.

Nemirovskii E.L. Ivan Fedorov. Nachalo knigopechataniia na Rusi: Opisanie izdanii i ukazatel' literatury: k 500-letiiu so dnia rozhdeniia velikogo russkogo prosvetitelia. Moscow, 2010. 